\title{
NO-sensitive guanylyl cyclase $\beta$ I subunit interacts with chromosomes during mitosis: novel role in the regulation of chromatin condensation

\author{
Paula Pifarré* ${ }^{* 1}$, María Antonia Baltrons ${ }^{\dagger 1}$, Verónca Davalos ${ }^{2}$, \\ Simon Schwartz Jr${ }^{2}$ and Agustina García ${ }^{1}$
}

\author{
Address: ${ }^{1}$ Institute of Biotechnology and Biomedicine and Department of Biochemistry and Molecular Biology, Autonomous University of \\ Barcelona, Spain and ${ }^{2}$ Molecular oncology Program, Molecular Oncology and Aging Group, Vall d'Hebron Hospital Research Institute, Barcelona, \\ Spain \\ Email: Paula Pifarré* - paula.pifarre@gmail.com \\ * Corresponding author †Equal contributors
}

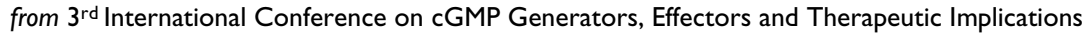

Dresden, Germany. 15-17 June 2007

Published: 25 July 2007

BMC Pharmacology 2007, 7(Suppl I):S43 doi:I0.1186/I47I-2210-7-SI-S43

This abstract is available from: http://www.biomedcentral.com/I47I-22/0/7/SI/S43

(c) 2007 Pifarré et al; licensee BioMed Central Ltd.

\section{Background}

NO-sensitive guanylyl cyclase $\left(\mathrm{GC}_{\mathrm{NO}}\right)$, the major $\mathrm{NO}$ target, exists as an obligate heterodimer of one $\alpha$ and one $\beta$ subunit. Two types of each subunit have been cloned $(\alpha 1-2, \beta 1-2)$, but only $\beta 1$ and $\alpha$ subunit expression has been reported in the CNS. In this tissue, in situ hybridization studies have shown that $\beta 1$ is more widespread than $\alpha$ subunits and in some areas is the only $\mathrm{GC}_{\mathrm{NO}}$ subunit expressed [1]. Since $\beta 1 / \beta 1$ homodimers are catalytically inactive the possibility of $\beta 1$ having functions other than $\mathrm{GC}_{\mathrm{NO}}$ activity has been suggested. $\mathrm{GC}_{\mathrm{NO}}$ is predominantly cytosolic, however recent studies suggest that it can associate to membranes and other intracellular structures including nuclei $[2,3]$.

\section{Results}

In the course of our studies on the cellular and sub-cellular distribution of $\mathrm{GC}_{\mathrm{NO}}$ subunits in CNS glial cells we have found that the $\beta 1$ subunit is localized in the cytoplasm and the nucleus in cells that also express $\alpha$ subunits and present $\mathrm{GC}_{\mathrm{NO}}$ activity (astrocytes), as well as in cells devoid of $\alpha$ subunits and $\mathrm{GC}_{\mathrm{NO}}$ activity (microglia). In both cases $\mathrm{GC}_{\mathrm{NO}} \beta 1$ associates peripherally to chromosomes in all phases of mitosis and appears to regulate mitotic chromatin condensation independent of cGMP formation. Moreover, silencing by siRNA increases the percentage of cells in the $S$ phase of the cell cycle and enhances proliferation.

\section{Conclusion}

The $\mathrm{GC}_{\mathrm{NO}} \beta 1$ subunit associates to chromosomes during mitosis and regulates chromatin condensation and cell cycle progression decreasing cell proliferation. This actions of $\mathrm{GC}_{\mathrm{NO}} \beta 1$ are independent of NO-dependent cGMP formation.

\section{Acknowledgements}

This work has been supported by Ministerio de Educación y Ciencia, Spain, SAF2004-017I7; Fellowship FPU 2000 to P. Pifarré.

\section{References}

I. Pifarre P, Garcia A, Mengod G: Species differences in the localization of soluble guanylyl cyclase subunits in monkey and rat brain. I Comp Neurol 2007, 500:942-947.

2. Nedvetsky PI, Sessa WC, Schmidt HH: There's NO binding like NOS binding: protein-protein interactions in NO/cGMP signalling. Proc Natl Acad Sci USA 2002, 99:16510-165I2.

3. Gobeil F, Zhu T, Brault S, Geha A, Vazquez-Tello A, Fortier A, Barbaz $D$, Checchin D, Hou $X$, Nader M, et al.: Nitric oxide signaling via nuclearized endothelial nitric-oxide synthase modulates expression of the immediate early genes iNOS and mPGESI. J Biol Chem 2006, 28 I:16058-16067. 